\title{
Creating cartoons to represent habitual leg movements
}

\author{
Desenvolvimento de modelos iconográficos \\ representativos de movimentos habituais de pernas
}

\author{
Karla CARLOS ${ }^{1,2}$, Eleida Pereira CAMARGO ${ }^{3}$, Mayara Menezes do MOINHO \\ Amanda Moraes de Paula SOUZA ${ }^{3}$, Melissa Haruka KUROIWA ${ }^{3}$, Gilmar Fernandes do PRADO ${ }^{1,2}$
}

\begin{abstract}
Many people have a habit of moving their legs and believe that this behavior is due to the restless legs syndrome (RLS), a highly prevalent neurological condition that greatly impairs the quality of life of affected individuals. This behavioral pattern, characterized by the habit of moving one's legs and feet, may be an important confounding factor in the diagnosis of RLS. Objective: To describe the main movements associated with this benign behavioral state to characterize a possible clinical condition that can contribute to the differential diagnosis of RLS. Methods: Experienced sleep specialists, who primarily see RLS patients listed the most frequent movements people without RLS report while describing their suspected RLS. We first compiled a list of the lower-limb movements described by the specialists. Then, one of the authors $(\mathrm{KC})$ carried out all movements of the list on camera to obtain a video footage. This footage was sent to one of the authors, EPC, who, alongside a group of students, drew graphic representations (cartoons) of the recorded movements. Results: The panel of sleep experts described 13 leg movements commonly reported by their patients. The experts reported 11 simple movements and two combined movements. Conclusion: In this study we developed an instrument that allows us to oppose and distinguish a pathological condition (RLS) from a behavioral phenomenon. This state of behavioral leg fidgeting needs to be better characterized and may eventually be recognized as a clinical entity per se.

Keywords: restless legs syndrome; movement; diagnosis.
\end{abstract}

\section{RESUMO}

Muitas pessoas têm o hábito de movimentar as pernas e acreditam que esse comportamento decorre da Síndrome das Pernas Inquietas (SPI), uma condição neurológica altamente prevalente com grande impacto na qualidade de vida dos indivíduos acometidos. Esse padrão de comportamento, caracterizado pelo costume de mover as pernas e os pés, pode ser um importante fator confundidor no diagnóstico da SPI. Objetivo: Descrever os principais movimentos associados a esse estado comportamental benigno, com a finalidade de caracterizar uma eventual condição clínica que possa contribuir para o diagnóstico diferencial da SPI. Métodos: Especialistas em distúrbios do sono, que atendem principalmente pacientes com SPI, listaram os movimentos que as pessoas sem SPI reportam com maior frequência enquanto descrevem a sua suspeita de síndrome. Elaboramos uma lista de movimentos dos membros inferiores descritos pelos especialistas e um dos autores (KC) realizou esses movimentos para que fossem gravados em vídeo. Essa filmagem foi enviada ao autor EPC, que, em conjunto com um grupo de alunos, realizou a representação gráfica (cartoon) dos movimentos gravados. Resultados: Os especialistas reportaram 13 movimentos de pernas, sendo 11 movimentos simples e dois movimentos combinados. Conclusão: Neste estudo, elaboramos um instrumento que permite opor, com a finalidade de diferenciá-las, uma condição patológica (SPI) de um fenômeno comportamental. Esse estado de inquietude comportamental das pernas necessita ser mais bem caracterizado, podendo eventualmente vir a ser reconhecido como uma entidade clínica per se.

Palavras-chave: síndrome das pernas inquietas; movimento; diagnóstico.

Many people have a habit of moving their legs and believe that this behavior is due to the restless legs syndrome (RLS), a highly prevalent neurological condition that greatly impairs the quality of life of affected individuals. This behavioral pattern, characterized by the habit of moving one's legs and feet, may be an important confounding factor in the diagnosis of RLS ${ }^{1}$.

Unlike the everyday habit of leg fidgeting, the main characteristic of the Restless Legs Syndrome/Willis-Ekbom disease (RLS/WED) is an irresistible urge to move the legs, usually

'Universidade Federal de São Paulo, Escola Paulista de Medicina, Departamento de Neurologia, São Paulo SP, Brazil.

${ }^{2}$ Neuro-Sono, São Paulo SP, Brazil.

${ }^{3}$ Faculdade de Arquitetura e Urbanismo da Universidade de São Paulo, São Paulo SP, Brazil.

Karla CARLOS ID https://orcid.org/0000-0002-6600-4587; Eleida Pereira CAMARGO ID https://orcid.org/0000-0001-8594-8869;

Gilmar Fernandes do PRADO (iD) https://orcid.org/0000-0002-3383-8198

Correspondence: Karla Carlos; Rua Claudio Rossi, 394; 01547-000 São Paulo SP, Brasil; E-mail:ka.carlos1@hotmail.com

Conflict of interest: There is no conflict of interest to declare.

Received on June 25, 2019; Received in its final form on September 18, 2019; Accepted on October 16, 2019. 
associated with an unpleasant sensation that occurs during rest, especially in the evening and night, which improves with movement and cannot be explained by other clinical or behavioral conditions ${ }^{1,2}$.

As movement is a core clinical feature of RLS, there may be some difficulty in distinguishing the disease from the nonpathological habit of leg fidgeting in various everyday situations ${ }^{3}$. In addition, the presence of the word "restless" in the name of the disease may suggest that repetitive movements are enough to characterize it, even though restlessness alone is not enough to define RLS/WED ${ }^{4}$. Diagnostic criteria have been updated over the years, and the expression "motor restlessness", for example, has been replaced by an "urge to move", demonstrating the concern of the IRLSSG to specify the reason why affected individuals perform these movements ${ }^{2,5}$.

In RLS/WED, leg movement is an important, imperative factor without which the individual cannot relieve the uncomfortable symptoms they experience. In the non-pathological behavior pattern, legs movement merely represents a habit; it does not serve the purpose of reducing or abolishing any discomfort or symptom felt in the legs ${ }^{6}$. On the other hand, individuals often move their legs without being fully aware of the movement or of the reason behind it, although it "feels good".

Some movement patterns have been more clearly described in the differential diagnosis of $\mathrm{RLS}^{3,7}$, including, for example, hypotensive akathisia, painful legs and moving toes, and neuroleptic-related akathisia ${ }^{8}$. However, to date, no studies have described and clearly characterized the movements associated with the benign behavioral state of leg fidgeting, which is often confused with RLS, not only by physicians but also by the general population, contributing to diagnostic errors and stigmatization of RLS patients, respectively.

The purpose of this study is to describe the main movements associated with this benign behavioral state to characterize a possible clinical condition that can contribute to the differential diagnosis of RLS.

\section{METHODS}

Experienced sleep specialists, who primarily see RLS patients, listed the most frequent movements that people without RLS report while describing their suspected RLS. In view of the difficulty of describing some movements, one of the authors $(\mathrm{KC})$ asked the participating experts to imitate the movements reported by patients. We attempted to classify those reported movements according to the moving joint, side, and posture of the legs.

This study was carried out jointly with students of the Design program of Universidade de São Paulo, School of Architecture and Urban Planning (FAU-USP) and was approved by the Research Ethics Committee of Universidade Federal de São Paulo (UNIFESP).

\section{Cartoons}

We first compiled a list of the lower-limb movements described by the specialists. Then, one of the authors (KC) carried out all movements of the list on camera to obtain a video footage. This footage was sent to one of the authors (EPC), who, alongside a group of students from USP Design program, drew graphic representations (cartoons) of the recorded movements. These cartoon representations should be simple and easy to recognize, to ensure applicability in future population-based studies. We used this criterion to select the best set of cartoons.

\section{Selection of cartoons}

Two authors (GFP and KC) analyzed the proposed cartoons and chose the set that best met the afore mentioned criteria of simplicity and ease of recognition.

\section{Classification of movements}

We classified movements as "simple" when they involved only one joint, whether unilaterally or bilaterally. Conversely, we classified those movements in which two or more joints were actively involved as "combined".

\section{Movement recognition test}

The selected set of cartoons (Figures 1 and 2) was presented to five neurologists who were participating in a Sleep
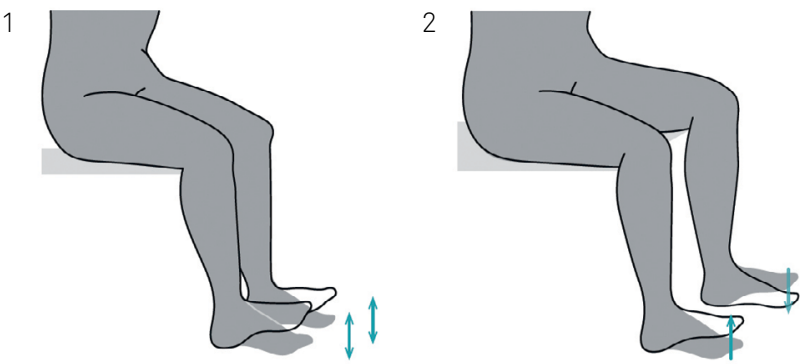

3

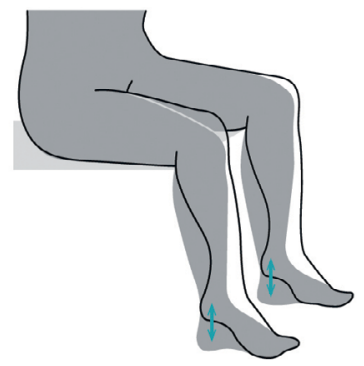

5

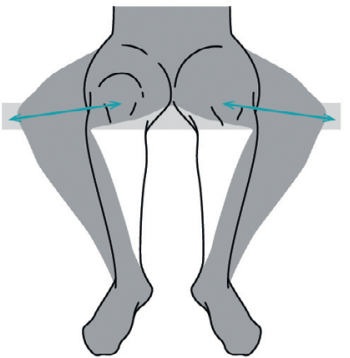

4
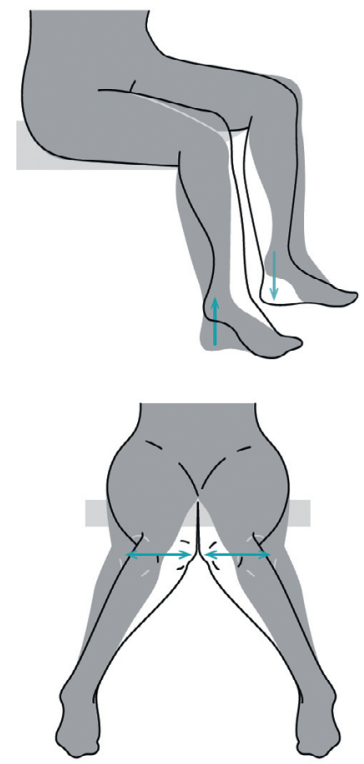

Figure 1. Representation of legs movements. 
Medicine fellowship program. The fellows were then asked to reproduce the illustrated movements. These physicians had not participated in any previous stage of the study.

\section{RESULTS}

The panel of sleep experts described 13 leg movements commonly reported by their patients, listed below according to the lower limb joints involved. The experts reported 11 simple movements (Table 1) and 2 combined movements (Table 2).

\section{Selection of cartoons}

We received 19 sets of cartoons and selected only one set, which represented the movements clearly and was easily interpreted. Even so, Movements 2, 3, and 4 were somewhat difficult to recognize (supplementary data).

In Movement 2, the cartoon gave the impression of four feet, as the legs were drawn very close to each other and the shading confused the actual movement, suggesting there were two feet moving up and two, moving down. In Movement 3, the left heel was not visible in the cartoon and the arrows were not aligned with the corresponding feet to indicate movement. In Movement 4, the shading of the cartoon was deemed confusing, making the interpretation of the
7
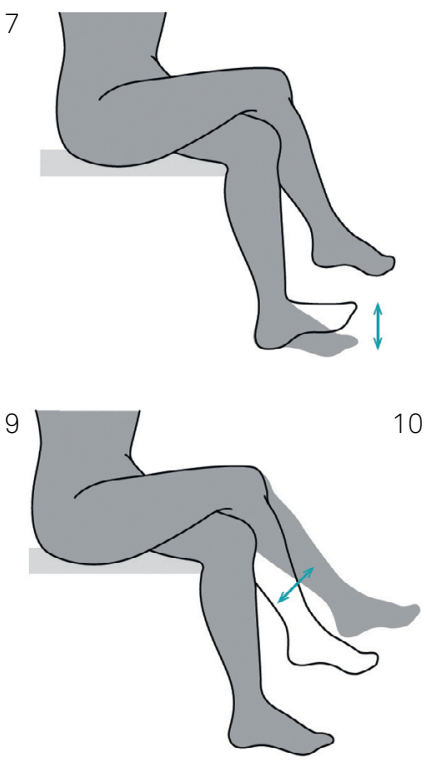

11

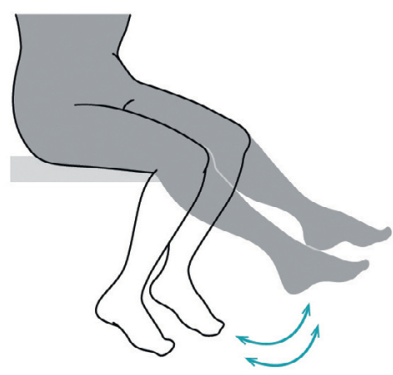

8

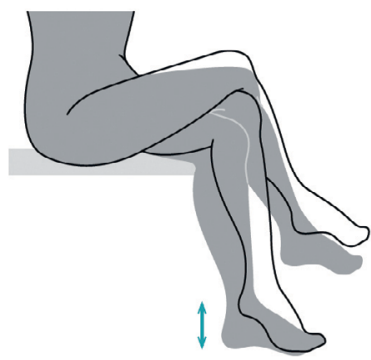

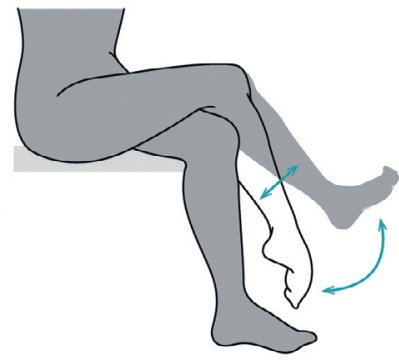

12

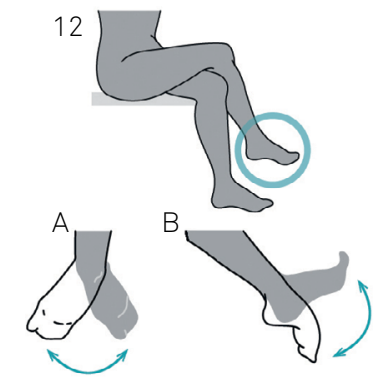

B

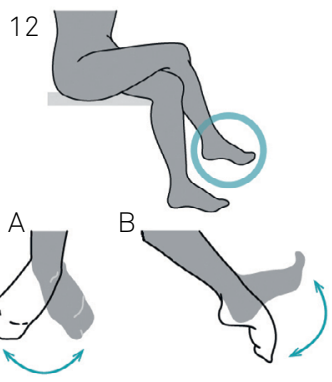

Figure 2. Representation of legs movements.

left lower limb position difficult. These issues were addressed, and a definitive set of figures was developed (Figures 1 and 2).

All sleep medicine fellows who participated in the movement recognition stage had no difficulty reproducing any of the movements correctly.

\section{DISCUSSION}

The main result of this study was the creation of an adequate visual representation of the movements most

Table 1. Simple movements.

\begin{tabular}{|c|c|c|}
\hline Movement & Description & Figure \\
\hline 1 & $\begin{array}{l}\text { Tapping toes on the floor, } \\
\text { both feet concomitantly }\end{array}$ & 1 \\
\hline 2 & $\begin{array}{l}\text { Tapping toes on the floor, } \\
\text { both feet alternately }\end{array}$ & 1 \\
\hline 3 & $\begin{array}{l}\text { Tapping heels on the floor, } \\
\text { both feet concomitantly }\end{array}$ & 1 \\
\hline 4 & $\begin{array}{l}\text { Tapping heels on the floor, } \\
\text { both feet alternately }\end{array}$ & 1 \\
\hline 5 & Abducting and adducting the thighs & 1 \\
\hline 7 & $\begin{array}{l}\text { Legs crossed, limb resting on the } \\
\text { contralateral thigh, heel of supporting } \\
\text { limb fixed and in contact with the } \\
\text { ground, forefoot moving up and down }\end{array}$ & 2 \\
\hline 8 & $\begin{array}{l}\text { Legs crossed, limb resting on } \\
\text { the contralateral thigh, forefoot } \\
\text { of supporting limb fixed and } \\
\text { in contact with the ground, } \\
\text { heel moving up and down }\end{array}$ & 2 \\
\hline 9 & $\begin{array}{l}\text { Legs crossed, popliteal region } \\
\text { over the thigh of the supporting } \\
\text { limb, flexing/extending the } \\
\text { knee of the overlying leg }\end{array}$ & 2 \\
\hline 11 & $\begin{array}{l}\text { Concomitant, bilateral knee } \\
\text { extension and semiflexion }\end{array}$ & 2 \\
\hline $12 \mathrm{~A}$ & $\begin{array}{l}\text { Legs crossed, popliteal region } \\
\text { over the thigh of the supporting } \\
\text { limb, foot of the overlying } \\
\text { leg moving up and down }\end{array}$ & 2 \\
\hline $12 \mathrm{~B}$ & $\begin{array}{l}\text { Legs crossed, popliteal region over } \\
\text { the thigh of the supporting limb, foot } \\
\text { of the overlying leg moving laterally }\end{array}$ & 2 \\
\hline
\end{tabular}

Table 2. Combined movements.

\begin{tabular}{lcc}
\hline Movement & Description & Figure \\
\hline 6 & $\begin{array}{c}\text { Internal rotation of the hip }+ \\
\text { adduction and abduction of the thigh }\end{array}$ & 1 \\
& Legs crossed, popliteal region \\
over the thigh of the supporting & \\
limb, flexing/extending the & 2 \\
knee of the overlying leg + & \\
ankle moving up and down & \\
\hline
\end{tabular}


commonly reported by individuals who experience habitual leg fidgeting.

The movements were easily identified even in version one of the set of cartoons; only movements 2, 3, and 4 required clarification, and, in the final version, were very clear and easy to recognize.

This study is an important step toward the creation of an instrument designed to differentiate patterns of movement associated with the benign habit of leg fidgeting from those of RLS/WED, a pathological condition with clinical consequences and impact on quality of life $\mathrm{e}^{9-10}$.

These cartoons may be part of future population-based studies aimed at identifying and increasing awareness of a phenomenon that is often mistaken for RLS/WED. Patients with RLS are stigmatized because, from the point of view of the general population, a medical diagnosis of RLS represents only the habit of moving one's legs, which we have termed as leg fidgeting - something that is far from representing a problem ${ }^{1,9}$. Friends and family often do not understand why patients with RLS need to take medications, as they presume they also have "restless legs" and cope well with it. People with this habit cannot see RLS as a real health condition, since they confuse the disease with benign leg fidgeting.

One weakness of this study is that our option for simplicity and lightness of the drawings could bring some difficulty of representation. The number of medical specialists interviewed was small, and no specialists from large cities were interviewed. An advantage of the present study was the use of simple lines and the aid of direction signals outside the drawing, making the drawings simpler and less numerous.

In summary, in this study we developed an instrument that allows us to oppose and distinguish a pathological condition (RLS) from a behavioral phenomenon ${ }^{3-7}$. This state of behavioral leg fidgeting needs to be better characterized and may eventually be recognized as a clinical entity per se.

\section{References}

1. Allen RP, Picchietti DL, Garcia-Borreguero D, Ondo WG, Walters AS, Winkelman JW, et al. Restless legs syndrome/Willis-Ekbom disease diagnostic criteria: update International Restless Legs Syndrome Study Group (IRLSSG) consensus criteria - history, rationale, description, and significance. Sleep Med. 2014 Aug;15(8):860-73. https://doi.org/10.1016/j.sleep.2014.03.025

2. Allen RP, Picchietti D, Hening WA, Trenkwalder C, Walters AS, Montplaisir J. Restless legs syndrome: diagnostic criteria, special considerations, and epidemiology. A report from the restless legs syndrome diagnosis and epidemiology workshop at the National Institutes of Health. Sleep Med. 2003 Mar;4(2):101-19.

3. Hening WA, Allen RP, Washburn M, Lesage SR, Earley CJ. The four diagnostic criteria for Restless Legs Syndrome are unable to exclude confounding conditions ("mimics"). Sleep Med. 2009 Oct;10(9):976-81. https://doi.org/10.1016/j.sleep.2008.09.015

4. Carlos K, Prado LBF, Carvalho LBC, Prado GFP. Willis-Ekbom Disease or Restless Legs Syndrome? Sleep Med. 2015 Sep;16(9):1156-9. https://doi.org/10.1016/j.sleep.2015.05.022

5. Walters AS. Toward a better definition of the restless legs syndrome. The International Restless Legs Syndrome Study Group. Mov Disord. 1995;10:634-42. https://doi.org/10.1002/mds.870100517
6. Chokroverty S. Differential diagnoses of Restless Legs Syndrome/ Willis-Ekbom disease mimics and comorbidities. Sleep Med Clin. 2015 Sep;10(3):249-62. https://doi.org/10.1016/j. jsmc.2015.05.021

7. Benes H, Walters AS, Allen RP, Hening WA, Kohnen R. Definition of Restless Legs Syndrome, How to Diagnose It, and How to Differentiate It from RLS Mimics. Mov Dis. 2007;22 Suppl 18:S401-8.

8. Associação Brasileira do Sono, Rizzo G (Coord.). Síndrome das Pernas Inquietas: Consenso Brasileiro 2013. $1^{\text {a }}$ ed. São Paulo: Omnifarma, 2013. 48p.

9. Varela MJV, Coin-Carvalho JE, Carvalho LBC, Varela MV, Potasz C, Prado LBF, et al. Restless Legs Syndrome: a qualitative analysis of psychosocial suffering and interdisciplinary attention.J Health Psychol. 2012;18(10):1341-52. https://doi. org/10.1177/1359105312439730

10. Carlos K, Prado GF. Exclusion of mimics does not influence Willis-Ekbom disease diagnosis among recent medical graduates. Arq Neuropsiquiatr. 2018 Dec;76(12):816-20. https://doi. org/10.1590/0004-282X20180135 